\title{
From French into Malay via English: The Indirect Translation of Henri Fauconnier's Malaisie into Malay
}

\author{
${ }^{*}$ INTAN SURAYA ZAINOL \\ HASLINA HAROON \\ School of Humanities, Universiti Sains Malaysia, 11800 USM Pulau Pinang, Malaysia \\ *Corresponding author: intan_suraya3093@yahoo.com
}

Published online: 31 October 2019

To cite this article: Intan Suraya Zainol and Haslina Haroon. 2019. From French into Malay via English: The indirect translation of Henri Fauconnier's Malaisie into Malay. KEMANUSIAAN the Asian Journal of Humanities 26(2): 105-122, https://doi.org/10.21315/kajh2019.26.2.5

To link to this article: https://doi.org/10.21315/kajh2019.26.2.5

\begin{abstract}
An indirect translation is a translation in language $\mathrm{C}$ which is produced not from the source text in language A but based on a mediating text in language $B$ which itself is a translation of the source text. One issue arising from indirect translation is the issue of fidelity, that is, the extent to which the translation reflects the original source text due to the presence of the mediating text. The aim of this paper is to examine this issue by focusing on a translation in Malay entitled Nurani Tanah Melayu, the English mediating text, The Soul of Malaya and the French source text, Malaisie. More specifically, the paper aims to determine the types of relationship that exist between the three texts and to establish the changes made by the translator in the process of translating. Ultimately, the aim is to establish whether the process of indirect translation produces a translated text that deviates from the original text and if so, whether the mediating text plays a role in the deviations that occur. For this purpose, a comparison is carried out between the three texts with the aim of establishing the similarities and differences between them. The findings indicate that the deviations from the French source text in the Malay translation are not necessarily due to the mediating text. Additionally, in cases where the Malay translation reflects the French source text, the adherence to the French text is not necessarily due to the assistance the mediating text.
\end{abstract}

Keywords and phrases: indirect translation, literary translation, intermediary text, mediated translation, Malay translation

\section{Introduction}

Translation is often seen as a straightforward process, involving the simple binary of source text and target text. This is, however, not always the case. Deru Ombak, the Malay translation of Yukio Mishima's Shiosai was not translated directly from 
the original Japanese but from The Sound of Waves, the English translation of the Japanese novel (Haroon and Abdul Majid 2015). Similarly, the Catalan translation of Joseph Conrad's Typhoon, was not produced directly from the novella in English but came about via a French translation of the English text (Coll-Vinent 1998). Translation in these cases involves not only the source text and the target text but also an intermediary text. This goes against what Hekkanen $(2014,47)$ refers to as the "gold standard" in literary translation, which is direct translation from the source text.

A text which is not translated directly from the source text but is instead translated based on an intermediary text which is itself a translation from the source text is referred to as an indirect translation. An indirect translation, abbreviated to "ITr" by Assis Rosa, Pięta and Maia (2017), can thus be defined as "a translation of a translation" (Assis Rosa, Pięta and Maia 2017, 113) or "translation into Language $\mathrm{C}$ based on a translation into Language B of a source text in Language A" (Landers 2001, 34). The fact that indirect translation involves three different texts in three different languages is also underlined by Kittel and Frank (1991, 3), who define indirect translation as "the translation based on a source (or sources) which is itself a translation into a language other than the language of the original, or the target language".

Indirect translation is also referred to by other names by scholars. Coll-Vinent $(1998,58)$ uses the term "mediated translation", which is defined as "translations made from previously produced, intermediate translation". St. Andre (2009, 230), meanwhile, uses the term "relay translation", which he defines as "the translation of a translated text (either spoken or written) into a third language". For Ringmar $(2012,141)$, who uses the term "relay translation", the process involves "a chain of (at least) three texts, ending with a translation made from another translation: (original) ST > intermediate text (IT) > (end) TT", where "ST" refers to the source text, "IT" to intermediate text and "TT" to target text.

\section{Issues in Indirect Translation}

Indirect translation has only recently been given proper attention by translation scholars, as seen in the number of important publications relating to indirect translation in recent years (see Assis Rosa, Pięta and Maia 2017; Ivaska and Paloposki 2018; Marin-Lacarta 2017; Pięta 2014; Pięta 2017). For the most part, an indirect translation is often seen in a negative light, primarily because it is produced not from the original source text but based on an intermediary text which is a translation of the source text. A translation on its own is often already viewed as a derivative text, a second-hand version of the original: an indirect translation 
suffers a worse fate as it is based on that second-hand version. In other words, "if translation is deemed bad, because derivative, ITr is worse" (Assis Rosa, Pięta and Maia 2017, 114). This is due to the fact that an indirect translation is "twice removed from the original. It is a translation of a translation: a double translation" (Kadiu 2016, 4).

One of the issues arising from indirect translation is the issue of fidelity, more specifically, the extent to which the resulting target text (TT) reflects the original source text (ST) due to the presence of the intermediate/mediating text (IT/MT). In other words, because a mediating text is used, it is likely that the resulting translation will differ from the original source text. Landers $(2001,131)$ compares the process of producing a translation based on a translation to the act of making a Xerox copy based on a copy: "a copy of a copy of a copy loses sharpness and detail with each successive passage through the process".

The loss that occurs in the process of translation is inevitable as modifications are bound to be made by the translator in transferring the message in a text from one language into another (Kadiu 2016, 1). To Dolllerup (2000, 23), some of the deviations that occur in indirect translation are due to cultural differences. This suggests that the modifications may be intentional. Modifications may also be due to mistakes on the part of the translator. When a translation is then carried out based on a translation which contains errors, the errors are then reproduced in the subsequent translation (Landers 2001, 131). The problem of fidelity to the source text is further compounded due to the fact that "more mistakes and distortions are added as one moves away from the original" (St. Andre 2009, 230). This results in "a cumulation of deviations" in the subsequent translation(s) (Dollerup 2000, 23). One consequence of the changes that are made in the process of indirect translation is that "fidelity and loyalty to the author become weakened, not out of ill will, but for practical reasons" (Dollerup 2000, 23). Indeed, one of the claims made regarding indirect translation is that it "arguably increases the distance to the ultimate ST” (Assis Rosa, Pięta and Maia 2017, 113).

The nature of the changes that take place in indirect translation can be determined by examining the similarities and differences between the three texts. Ringmar $(2007,10)$, for instance, notes that with the use of the mediating text in indirect translation, "the TT differs more from the ST than the MT differs from the ST". In other words, the resulting translation becomes more distant from the original source text, which is the claim often made regarding indirect translation.

Meanwhile, the study carried out by Kadiu (2016), which involves an Albanian source text (A), its French translation (F) and the French-based English translation 
(E), examined the changes between the target text and the source text and the extent to which the mediating text played a role in these changes. Four main patterns of relationship in indirect translation can be determined. Although Kadiu (2016) uses the initials A, F and E to represent the three languages involved in indirect translation in her study, here A, F and E are replaced with ST, MT and TT respectively in order to make clear the nature of the relationship between the three texts. The four main patterns in Kadiu's (2016) study are as follows:

1. $\mathrm{ST} \neq \mathrm{MT}$ and $\mathrm{MT}=\mathrm{TT}$. In this instance, deviations from the ST which are found in the MT are repeated in the TT. As such, the use of the MT can be said to affect the fidelity of the TT to the original ST.

2. $\mathrm{ST} \neq \mathrm{MT}$ and $\mathrm{MT} \neq \mathrm{TT}$. In this instance, the MT deviates from the ST and the TT also deviates from the MT. In this case, the TT deviates from the ST but the changes that occur in the TT are not due to the use of the MT because the translator does not follow the MT.

3. $\mathrm{ST}=\mathrm{MT}$, but $\mathrm{MT} \neq \mathrm{TT}$. In this instance, despite the fact that the MT follows closely the ST, the TT does not follow the MT. As such, the changes that occur in the TT in this case are not due to the use of the MT because the translator does not follow the MT.

4. $\mathrm{ST} \neq \mathrm{MT}$ and $\mathrm{MT} \neq \mathrm{TT}$, but $\mathrm{TT}=\mathrm{ST}$. In this instance, the MT deviates from the ST and the TT also deviates from the MT. This is similar to the situation in no. 2. However, unlike in no. 2 where the TT shows deviations from the ST, here the TT in fact resembles the ST.

In addition to that, there are also instances where the target text simultaneously follows and deviates from the MT and/or the ST. Because this particular type of relationship does not involve a specific pattern but encompasses a variety of similarities, differences and inconsistent changes between the three texts, no diagrammatic representation is offered by Kadiu (2016).

Taking into account issues regarding how the source text, mediating text and target text relate to one another in indirect translation and whether the resulting translation deviates from the original source text due to the presence of the mediating text, this study aims to explore these issues by focusing on a translation in Malay entitled Nurani Tanah Melayu, the mediating text in English entitled The Soul of Malaya and the source text in French entitled Malaisie. More specifically, the study aims to do the following: 
1. to determine the types of relationship between the French source text, the English mediating text and the Malay translation,

2. to determine the changes and adjustments that are made in the process of translating from French into Malay via English and

3. to establish whether the process of indirect translation produces a translated text that deviates from the original source text.

\section{Data and Methodology}

The data in this preliminary study are extracted from three texts: a French source text, the English mediating text and the Malay translation. Malaisie, the French source text, was written by Henri Fauconnier and was first published by Librairie Stock in Paris in 1930. Set in British Malaya in the 1920s, the novel revolves around two Frenchman - Rolain, the owner of a rubber plantation and Lescale, the manager of Rolain's rubber estate who is the narrator of the story, and two Malays - Smail, Rolain's servant and Ngah, Smail's younger brother who is also Lescale's servant. Malaisie won the Prix Goncourt, France's most prestigious literary award, in 1930. In 1931, Malaisie was translated into English by Eric Sutton with the title The Soul of Malaya. The translation was published by Elkin Mathews \& Marrot in London.

The Malay translation, Nurani Tanah Melayu, was published in 2015 in Kuala Lumpur by Institut Terjemahan dan Buku Malaysia (ITBM). The cover of the translation bears the title in Malay, Nurani Tanah Melayu and also the title of the source text, Malaisie, below the Malay title. The inclusion of the title of the French source text gives readers the impression that the text is translated directly from the French. This is, however, not the case. The Malay translation, in fact, was carried out based on The Soul of Malaya, the English translation of Malaisie, as explained by the translator, Muhammad Haji Salleh, in the preface to the Malay translation, "Oleh sebab penguasaan bahasa Perancis saya sangat asas, saya telah menggunakan terjemahan Eric Sutton ke dalam bahasa Inggeris, yang diberi judul The Soul of Malaya" (Fauconnier 2015a, viii). Within a few months, he realised that he did not have to rely on Sutton entirely ("saya sedar bahawa saya tidak perlu bergantung pada Sutton sepenuhnya") (ibid.). He therefore enlisted the help of a reviewer by the name of Deborah Chow to check and revise the translation. According to Muhammad Haji Salleh, with the help of Deborah Chow, the voice and message of Fauconnier came through in the Malay translation: "Tindakan ini pula dibalas dengan penyemakan kerja saya dengan karya Perancisnya dengan 
sangat murah hati dan teliti. Dengan berbuat demikian, terjemahan saya dibawa ke inti suara dan bicara Fauconnier" (ibid.). Muhammad Haji Salleh also mentioned enlisting the help of his good friend, Dr Laurent Metzger, to undertake the final checks on the Malay translation (ibid.).

It is evident from the translator's preface that the Malay translation is an indirect translation which was produced not from the French original but from the English translation of the French text. Sutton's The Soul of Malaya in this case is both a translation (from the French source) and a source text (for the Malay translation). The provision of the background information regarding the Malay translation by the translator himself in the translator's preface not only tells the readers the text which was used as a basis for the Malay translation but also is in line with the suggestion made by Landers $(2001,131)$ that "an ethical translator is duty-bound to inform readers, perhaps in a translator's introduction, that the text at hand is not a first-generation translation".

In order to determine the types of relationship that exist between the three texts and to establish whether the resulting translation in Malay deviates from the French source text because of the mediating text, it is necessary to compare the Malay translation with both the English mediating text and the French source text. Each sentence in the French source text is therefore paired with its English and Malay counterparts. The types of relationship which exist between the three texts are determined by drawing upon the types of relationship in indirect translation as proposed by Kadiu (2016). Next, the changes that take place within each relationship are analysed using the techniques of adjustment proposed by Nida (1964), which comprise additions, subtractions and alterations. Although these techniques are discussed by Nida in the context of Biblical translations, they are, according to Nida $(1964,227)$, "equally applicable to all types of translating".

\section{Analysis and Discussion}

This section will discuss the different types of relationship which exist between the three texts based on the analysis carried out. In the examples provided to illustrate the different types of relationship, the French source text (ST) will be presented first, together with a gloss in English. Next, the corresponding English mediating text (MT) is presented, followed by the Malay target text (TT). Besides examining the relationship between the three texts, this section will also examine whether the Malay translation deviates from the French source text due to the presence of the mediating text. 
Based on the analysis carried out, two general types of relationship exist between the three texts. The first one involves very little change between the three texts in terms of its content, while the second involves changes in the texts.

\section{No deviation in the texts}

The first type of relationship is where there is very little or no change between the three texts. In other words, the English mediating text does not deviate from the French source text in terms of its content and the Malay translation similarly does not deviate from the English mediating text. Because of the close resemblance between the English text and the French text and between the Malay text and the English text, the Malay translation, as a result, closely reflects the French source text. This relationship can be represented in the following way: $\mathrm{ST}=\mathrm{MT}=\mathrm{TT}$ and $\mathrm{TT}=\mathrm{ST}$. Examples of this type of relationship can be seen in the following:

\section{Example 1}

ST: [La distance], [de] [Kuala Paya], [n'est que] [d'un centaine] [de milles]. (p. 18)

[the distance], [from] [Kuala Paya], [is only] [one hundred] [miles]

MT: The distance, from Kuala Paya, is only about a hundred miles. (p. 13)

TT: Jarak dari Kuala Paya hanya kira-kira 100 batu. (p. 8)

In Example 1, the content of the English mediating text is similar to that of the French source text. Because the Malay translation too follows closely the English mediating text, the Malay translation, as a result, does not deviate from the French source text. The similarities between the three texts can also be seen in Example 2.

Example 2

ST: [Je] [fis] [ce soir-là] [la connaissance] [de] [ nombreux] [démons]. (p. 118)

[I] [made] [that night] [the acquaintance] [of] [many] [demons]

MT: $\quad$ That night I made the acquaintance of numerous demons. (p. 67)

TT: Malam itu saya diperkenalkan kepada banyak jenis hantu. (p. 67).

Compared to the text in Example 1, this text involves a slight restructuring of the French text in the process of translation into English. The phrase ce soir-là (lit. that night) in the French source text is moved to the beginning of the sentence in 
the English translation. The meaning of the whole sentence, however, remains the same. The Malay translation meanwhile follows the structure of the mediating text. Therefore, while there is a slight difference between the structure of the Malay translation and the French source text, the content remains essentially the same. There is no deviation where content is concerned.

\section{Deviations in the texts}

The second type of relationship involves deviations in the texts which are compared. Four subtypes are identified.

\section{Subtype 1: The mediating text deviates from the source text, but the translation follows the mediating text}

In the first type of relationship within this category, the English mediating text differs from the French source text. The Malay translation, meanwhile, follows the English mediating text. Because of the reliance of the Malay translation on the English mediating text, the Malay translation also, as a result, deviates from the French source text. This relationship is best represented in the following way: ST $\neq \mathrm{MT}=\mathrm{TT}$ and $\mathrm{TT} \neq \mathrm{ST}$ and is exemplified in the following.

The deviation of the English mediating text from the French source text appears in different forms. The first involves additional information in the English translation, as seen in the following example.

\section{Example 3}

ST: [Comment] [n'avais-je pas] [pensé] [qu'en] [effet] [ce fruit], [qui] [contient] [la science] [du] [bien] [et] [du] [mal], [c'était] [la morale]? (p. 184)

[how] [did I not] [think] [that] [indeed] [this fruit] [which] [contains] [the science] [of ] [good] [and] [of] [evil] [it was] [morality]

MT: How was it I had never realised that the fabled fruit, which contained the knowledge of good and evil, was morality? (p. 104)

TT: Mengapakah saya tidak sedar bahawa buah daripada fabel itu mengandungi pengetahuan tentang baik dan buruk, iaitu akhlak? (p. 108)

In this example, a character by the name of Lescale uses the phrase ce fruit to refer to the fruit from the tree of the knowledge of good and evil which, according to Biblical tradition, was consumed by Eve after being persuaded to do so by a 
serpent in the Garden of Eden. In the English translation, the adjective "fabled" is added, resulting in "the fabled fruit". The English translator thus makes it clear in his translation that the "fruit" in this context refers to the forbidden fruit in the fable of Adam and Eve. The Malay translator reproduces "the fabled fruit" literally in the Malay translation, resulting in buah daripada fabel itu (lit. the fruit from the fable). In this case, the Malay translation deviates, albeit slightly, from the French source text. Both texts refer to the same forbidden fruit. In the Malay translation, however, the reference to the forbidden fruit of the Biblical story becomes more explicit when the translator describes it as buah daripada fabel itu. Because the Malay translation follows the English mediating text, it can be said that the deviation of the Malay text from the French source text is due to the presence of the mediating text.

\section{Subtype 2: The mediating text deviates from the source text and the translation deviates from the mediating text}

In the second type of relationship within the second category, the English mediating text deviates from the French source text and the Malay translation too deviates from the English mediating text. As a result, all the three texts are different from one another. This relationship is best represented in the following way: ST $\neq \mathrm{MT}$ $\neq \mathrm{TT}$ and $\mathrm{TT} \neq \mathrm{ST}$. One example of this type of relationship is shown in Example 4 , which involves alteration.

Example 4

ST: [On] [a coupé] [d'abord] [le sous-bois], [qui] [obstrue] [tout], [mais] [où] [les Malais] [passent] [comme] [des singes]. (p. 227) [we] [cut] [first] [the undergrowth] [which] [obstructs] [all] [but] [where] [the Malays] [pass] [like] [monkeys]

MT: The dense undergrowth, through which Malays dart about like monkeys, has first to be chopped away. (p. 128

TT: $\quad$ Tumbuhan renek dan belukaryang tebal, tempat orang Melayu menyelinap seperti haiwan, pertama sekali harus dicantas. (p. 135)

In the excerpt shown in Example 4, Lescale describes the process of clearing the jungle. He explains that le sous-bois, qui obstrue tout (lit. the undergrowth which obstructs everything) first had to be removed. This detail in the French source text is altered in the English translation, resulting in "the dense undergrowth". This change in the English translation is then repeated in the Malay translation, resulting in tumbuhan renek dan belukar yang tebal (lit. shrubs and thick underbrush). The change from le sous-bois, qui obstrue tout (lit. the undergrowth which obstructs 
everything) to tumbuhan renek dan belukar yang tebal in the Malay translation therefore can be said to be due to the reliance of the Malay translator on the English mediating text.

It must be noted, however, that the difference between the Malay translation and the French source text in this particular example is not only due to the mediating text. Lescale mentions in the excerpt in Example 4 that the Malays like to dart about through the thick undergrowth in the jungle comme des singes (lit. like monkeys). This comparison is made probably due to the familiarity of the Malays with the environment in the jungle. Sutton retains the comparison in the English translation. The Malay translator, however, alters the image altogether. In the Malay translation, the Malays are compared not to monyet (lit. monkeys) but instead to the more general haiwan (lit. animals). While the reason behind the change is not clear, it is assumed that this is due to the negative connotation associated with both "monkey" and monyet. In English, the word "monkey" connotes playfulness and also dishonesty (as in the expression "monkey business"). Similarly, in Malay, the word monyet is found in expressions which have mostly negative meaning, for example memberi bunga kepada monyet (lit. giving a flower to a monkey), which means giving something to someone who does not know how to appreciate it and berjual pisang kepada monyet (lit. selling bananas to a monkey), which means selling on credit. This particular example shows very clearly that the deviation of the target text from the source text is due not only to the presence of the mediating text but also to the intervention of the translator.

In the following example, the Malay translation again departs from the French source text. In this particular instance, however, the deviation can be said to be caused solely by the translator.

\section{Example 5}

ST: [II] [n'abaissait] [ce] [dais] [qu'en ma presence] [et] [montrait] [un] [visage] [de] [nèfle] [blette], [une] [poitrine] [cousue] [de fil blanc], [un] [ventre] [plat], [brun], [finement plissé], [comme] [une] [gaufre] [trop cuite]. (p. 59)

[he] [lowered] [this] [canopy] [in my presence] [and] [showing] [one] [face] [of] [medlar] [overripe], [one] [chest] [sewn] [with white thread] [one] [belly] [flat] [brown] [finely wrinkled] [like] [one] [waffle] [overcooked]

MT: $\quad$ He lowered this canopy only in my presence, displaying a face like a parched medlar, a chest criss-crossed with white hair and a flat brown belly, faintly lined, like an over-cooked griddle-cake. (p. 36) 
TT: Dia menurunkan payung itu hanya di hadapan saya, dan memperlihatkan wajah seperti buah setar yang kecut, dadanya ditutupi penuh oleh bulu putih, dan perutnya leper serta berwarna coklat, bergaris halus, seperti seketul kek yang terlalu lama berada di dalam ketuhar. (p. 31)

The excerpt in Example 5 describes one of the kanganies at the plantation. He is described in the French source text as having a flat, brown belly comme une gaufre trop cuite (lit. like an overcooked waffle). The English translation does not retain this image and instead compares the belly to "an over-cooked griddlecake". The readers of the English text are therefore presented with an image that is different from the image presented to the source text readers. Similarly, the Malay translation does not follow the English text and instead presents the readers with the image of a belly seperti seketul kek yang terlalu lama berada di dalam ketuhar (lit. like a cake that has been in the oven for too long). The resulting translation in Malay is thus different from both the English mediating text and the French source text. In this particular case, the deviation of the Malay translation from the French source text is not caused by the presence of the English mediating text but due to the translator's own creativity in creating an image believed to be more suited to his target readers, i.e. a cake, instead of a griddle-cake or a waffle.

The translator's role in the deviation of the Malay translation from the French source text can also be observed in the following example.

\section{Example 6}

ST: "... [Avant] [de passer] [le fer], [je l'ai] [vu] [s'emplir] [les joues] [d'eau] [et] [la ressouffler] [en] [douche] [fine] [sur] [mes] [chemises] [avec] [un bruit] [de] [diarrhee]..." (p. 133)

[before] [passing] [the iron], [I have] [seen] [fill] [his cheeks] [of water] [and] [blow] [in] [shower] [fine] [on] [my] [shirt] [with] [the sound] [of] [diarrhoea]

MT: $\quad$ "...Before he puts the iron on, I've seen him fill his cheeks with water and splutter it in a fine spray over my shirts..." (p. 102)

TT: $\quad$ "...Sebelum dia mula menyeterika, dia akan memenuhkan pipinya dengan air lalu menyemburkannya pada baju saya, seperti orang yang sedang cirit..." (p. 78)

This excerpt describes one of the irritating ways of Ha Hek, the Chinese helper at Rolain's bungalow. In the French source text, the readers are told that before he 
does the ironing, he fills his cheeks with water and then sprays the water from his cheeks onto the linen being ironed. While releasing the water en douche fine (lit. in a fine shower) from his cheeks, he produces un bruit de diarrhea (lit. the sound of diarrhea). Of these two descriptions, only one makes it to the English translation, that is, the description of the way the water is sprayed from the cheeks.

The description of the way the water is sprayed is, however, omitted in the Malay translation. As such, the deviation of the Malay text from the French source text here is due to the translator's intervention. It must be noted that despite the fact that the sound of the water being sprayed from the cheeks is omitted in the English translation, the description somehow appears in the Malay translation. This is evident in seperti orang yang sedang cirit (lit. like a person with diarrhea). The fact that this addition accurately reflects the French source text in spite of the omission of the same description in the English mediating text suggests a number of possibilities. First, the translator, despite his rudimentary knowledge of French, might have directly consulted the source text. Second, the reviser appointed by the translator might also have played a role by adding the missing portion back to the target text.

\section{Subtype 3: The mediating text reflects the source text, but the translation deviates from the mediating text}

The third type of relationship is where the French source text and the English mediating text are similar in content, but the Malay translation deviates from the English mediating text. Because of this, the Malay translation also deviates from the French source text. This is best represented by the following: ST $=\mathrm{MT} \neq \mathrm{TT}$ and $\mathrm{TT} \neq \mathrm{ST}$.

In some cases, the difference between the Malay translation and the two other texts lies in the additional information provided in the Malay translation. This can be seen in the following examples.

\section{Example 7}

ST: [Mais] [Rolain] [souriait] [à] [ces] [scènes] [dantesques]. (p. 130) [but] [Rolain] [smiled] [at] [these] [scenes] [Dantesque]

MT: But Rolain smiled at these Dantesque visions. (p. 99)

TT: Akan tetapi, Rolain hanya tersenyum apabila mendengarkan citra seperti seksa manusia dalam neraka yang disyairkan oleh Dante. (p. 76) 
As seen in Example 7, the mediating text in English ("these Dantesque visions") is a literal translation of the French source text (ces scènes dantesques). The translation in Malay, however, differs slightly from the source and mediating texts in that it provides the readers with additional information which may assist them in their understanding of the text. Ces scènes dantesques/"these Dantesque visions" in this context refers to visions of hell as described by the Italian poet, Dante Alighieri in his narrative poem, Divine Comedy. While the details of the "visions" are not clearly stated in both the source and mediating texts, they are made explicit by the translator in the Malay translation.

The provision of additional information in the Malay translation can also be seen in Example 8.

Example 8

ST: "... [Mais] [transporte] [Smaill] [aux] [Folies-Bergère], [et] [il se croira] [au] [paradis]..." (p. 185)

[but] [transport] [Smail] [to] [Folies-Bergère] [and] [he will believe himself] [in] [paradise]

MT: $\quad$ "...but transport Smail to the Folies-Bergère and he will believe himself in paradise..." (p. 143)

TT: $\quad$ "...tetapi bawa Smail ke pertunjukan Folies-Bergère, dengan penari yang tanpa pakaian itu, tentu dia akan berasa seperti di syurga..." (p. 108)

In this example, both the mediating text and the Malay translation retain the reference to "Folies-Bergère", the famous French cabaret hall which features cabaret dancers. The Malay translation, however, makes the reference to "FoliesBergère" more explicit, not only by referring to it as pertunjukan Folies-Bergère (lit. the Folies-Bergère show) but also by describing it as a show dengan penari yang tanpa pakaian (lit. with dancers who are without clothes).

Besides changes in the form of addition, there are also changes in the form of alteration. In such cases, the Malay translation differs from the mediating text and the source text in that the translation is altered, presumably to suit the Malayspeaking readers. This is exemplified in the following examples: 
Example 9

ST: [Et] [puis], [c'était] [vendredi], [le dimanche] [malais]. (p. 150) [and] [then] [it was] [Friday], [Sunday] [Malay]

MT: $\quad$ And it was Friday, the Malay Sunday. (p. 116)

TT: Hari itu pula ialah Jumaat, hari minggu orang Melayu. (p. 87)

In Example 9, Lescale refers to vendredi (Friday) as le dimanche malais (lit. the Malay Sunday). For many Malays and Muslims, Friday holds a special significance as it is a day of rest. In terms of its significance, it is equivalent to "Sunday" in many Western countries, where Sunday is also observed as a day of rest. The phrase le dimanche malais is reproduced literally by Sutton in the English translation. The Malay translator, however, drops the comparison altogether, possibly due to the fact that describing Friday as "the Malay Sunday" would not be meaningful to his Malay-speaking readers due to the fact that Muslims do not keep Sunday as a day of rest. The Malay translator instead plainly states that Jumaat (Friday) is hari minggu orang Melayu (lit. the Malay weekend). It must be noted that the meaning of "rest" is still retained in the translation, but it is conveyed using a different referent, i.e. the more general hari minggu (lit. weekend) in the Malay translation instead of the more specific "Sunday" in the mediating text.

Still another case of alteration can be seen in the following:

Example 10

ST: "...[Mais] [ils] [auront] [une fête] [à preparer], [des offrandes] [au] [Démon]..." (p. 23)

[but] [they] [will have] [a festival] [to prepare], [offerings] [to] [the Devil]

MT: "...But they have to prepare for a festival and get their offerings for those old Devils of theirs..." (p. 17)

TT: $\quad$ "...Tapi mereka sedang bersiap-siap untuk ke pesta dan perlu membeli persembahan untuk tuhannya..." (p. 12)

In this excerpt, the Tamil coolies at the plantation are getting ready for the festival of Deepavali, during which they prepare offerings au Démon (lit. to the Devil). The English translation retains the reference to the devil, although there is a slight change in the English translation, i.e., the singular Démon in the French source text is changed into the plural form, "Devils" and it is preceded in the English 
translation by the adjective "old". In the Malay translation, the Tamil coolies are described as buying offerings untuk Tuhannya (lit. for his/her God/Deity).

Examples 7 8, 9 and 10 all show the Malay translation deviating from the original French source text. In all these cases, the deviation cannot be attributed to the English mediating text, as the English text follows closely the French source text. In these cases, it is the translator's own personal choices which determine the decisions made in the Malay translation and which ultimately lead to the departure of the Malay translation from the original source text in French.

\section{Subtype 4: The mediating text deviates from the source text and the translation deviates from the mediating text}

The fourth type of relationship in this category is where the English mediating text differs from the French source text. The Malay translation too does not follow the English mediating text. What makes this case particularly interesting is that because the English translation does not follow the French source text and also because the Malay translation does not follow the English mediating text, it is assumed that the Malay translation would also not follow the French source text. In this particular case, however, the Malay translation actually reflects the French source text. This relationship can be represented in the following way: ST $\neq$ MT and $\mathrm{MT} \neq \mathrm{TT}$ but $\mathrm{TT}=\mathrm{ST}$.

One example of this type of relationship involves alteration. In this instance, an element in the French source text is altered into a different element altogether in the English translation. The change in the English text, however, is not reflected in the Malay translation. The Malay translation in fact appears to follow the French source text. This can be seen in Example 11.

Example 11

ST: [Entre temps], [il] [portait] [l'eau] [et] [allait] [au] [village] [acheter] [des provisions]. (p. 62)

[meanwhile] [he] [carry] [water] [and] [go] [to] [village] [buy] [provisions]

MT: $\quad$ From time to time he brought in wood, or went to the village to buy provisions. (p. 37)

TT: Kadang-kadang dia mengangkut air atau pergi ke kampung di luar sana untuk membeli barang keperluan. (p. 33) 
The excerpt in Example 11 is Lescale's description of Karuppan, Rolain's Tamil gardener. In the French source text, Karuppan helps around by carrying l'eau (lit. water) to the bungalow. Sutton, however, does not follow the detail provided in the French text; therefore, in the English translation, Karuppan carries "wood" instead of l'eau to the bungalow. Despite the change made in the English translation, the word l'eau somehow finds its way back to the Malay translation. Thus, in the Malay translation, the readers are told that Karuppan mengangkut air (lit. carries water) to the bungalow.

The close adherence of the Malay translation to the French source text, despite the alteration made in the English mediating text, points to the possible use of the original source text in French, either by the translator or the appointed reviewer.

This study has shown that the relationship that exists between the Malay translation, the mediating text in English and the source text in French can generally be divided into two general types. The first involves no change between the three texts and the second involves changes, which are of four different subtypes. Changes that are made in the texts are in the form of addition, alteration and omission.

The examples shown in this preliminary study also indicate that in the process of indirect translation, there are instances where the Malay translation departs from the French source text and also instances where the Malay translation reflects the French original. In cases where the Malay translation deviates from the French original, the examples indicate that this is at times due to the intervening role of the mediating text. In other words, the Malay translation deviates from the French source text because of the reliance of the Malay translator on the mediating text, in which changes have been made by the English translator in the process of translating from French into English.

We have, however, also observed that the deviations in the Malay translation from the French text are also attributable to the translator. The deviations occur because not only does the translator carry out the translation based on a mediating text which is already markedly different from the original French text, the translator also introduces more changes to his own translation as he sees fit. Meanwhile, in some other cases, changes are incorporated into the Malay translation by the translator in spite of the fact that the mediating text closely adheres to the original French. The translator thus exercised his prerogative in carrying out his translation. The findings in this preliminary study thus indicate that where the Malay translation deviates from the French source text, this is not necessarily due to the mediating text. 
In addition to that, there are also instances where the Malay translation reflects the French source text in the process of indirect translation. We have, however, seen that but this is not necessarily due to the assistance of the mediating text. In some cases, the Malay translation accurately reflects the French source text despite the changes made in the English mediating text. This suggests that the translator did not rely solely on the mediating text and perhaps occasionally, has recourse to the French text. The role of the appointed reviser also cannot be overlooked, as it is possible that the reviser has played a collaborative role in the translation.

\section{Conclusion}

This study has tried to explore the issue of fidelity to the original source text in indirect translation. It can be concluded that the mediating text does play a role in affecting the fidelity of the resulting translation to the original source text. The mediating text, however, is not the only factor that drives the outcome. The translator, by exercising his prerogative in the process of translating, also introduces changes which ultimately contribute to the deviation of the target text from the original source text.

The study also shows that the adherence of the target text to the original source text is not necessarily due to the presence of the mediating text, as the translator may have accessed the source texts directly or may have enlisted the help of a third party to check the translation against the original source text. More studies therefore need to be carried out on indirect translation in order to examine the role of the mediating text in the process. Textual analysis in studies such as this can perhaps be complemented by interviews with translators and reviewers so as ascertain their own mediating roles in the process of indirect translation.

\section{Acknowledgements}

This research was supported by the Universiti Sains Malaysia Bridging Grant (304.PHUMANITI.6316304).

\section{Bibliography}

Coll-Vinent, S. 1998. The French connection: Mediated translation into Catalan during the interwar period. The Translator 4(2): 207-228.

Dollerup, C. 2000. "Relay" and "support" translations. In Translation in context: Selected contributions from the EST Congress, eds. A. Chesterman, N.G. San Salvador and Y. Gambier, 17-26. Amsterdam: John Benjamins. 
Fauconnier, H. 2015a. Nurani Tanah Melayu, trans. Muhammad Haji Salleh. Kuala Lumpur: Institut Terjemahan dan Buku Malaysia.

_ 2015b. The soul of Malaya, trans. E. Sutton. Singapore: Editions Didier Millet. 1930. Malaisie. Paris: Librairie Stock.

Haroon, H. and Abdul Majid, M. 2015. The translation of foreign novels into Malay by Dewan Bahasa dan Pustaka. Malay Literature 28(1): 126-156.

Hekkanen, R. 2014. Direct translation: Is it the only option? Indirect translation of Finnish prose literature into English. In True north: Literary translation in the Nordic countries, ed. B.J. Epstein, 47-64. Newcastle upon Tyne: Cambridge Scholars Publishing.

Honeyman, N.P. 2005. From Arabic to other languages through English. In Less translated languages, eds. A. Branchadell and L.M. West, 67-74. Amsterdam/Philadelphia: John Benjamins.

Ivaska, L. and Paloposki, O. 2018. Attitudes towards indirect translation in Finland and translators' strategies: Compilative and collaborative translation. Translation Studies 11(1): 33-46. https://doi.org/10.1080/14781700.2017.1399819

Kadiu, S. 2016. David Bellos' indirect translation of Ismail Kadare's The File on H: A contextual analysis. IJLL International Journal Literary Linguistics 5(3): 1-24.

Kittel, H. and Frank, A.P. 1991. Introduction. In Interculturality and the historical study of literary translations, eds. H. Kittel and A.P. Frank, 3-4. Berlin: Erich Schmidt Verlag.

Landers, C.E. 2001. Literary translation: A practical guide. Clevedon, UK: Multilingual Matters.

Marin-Lacarta, M. 2017. Indirectness in literary translation: Methodological possibilities. Translation Studies 10(2): 133-149. https://doi.org/10.1080/14781700.2017.12862 55

Nida, E.A. 1964. Toward a science of translating, with special reference to principles and procedures involved in Bible translating. Leiden, Netherlands: E.J. Brill.

Pięta, H. 2017. Theoretical, methodological and terminological issues in researching indirect translation: A critical annotated bibliography. Translation Studies 10(2): 198-216. https://doi.org/10.1080/14781700.2017.1285248

- 2014. What do (we think) we know about indirectness in literary translation? A tentative review of the state-of-the-art and possible research avenues. In Traducció indirecta en la literatura catalana, eds. I.G. Sala, D.S. Roig and B. Zaboklicka, 15-34. Lleida, Spain: Punctum.

Rosa, A.A., Pięta, H. and Maia, R.B. 2017. Theoretical, methodological and terminological issues regarding indirect translation: An overview. Translation Studies 10(2): 113132. https://doi.org/10.1080/14781700.2017.1285247

Ringmar, M. 2012. Relay translation. In Handbook of translation studies (vol. 3), eds. Y. Gambier and L. Van Doorslaer, 141-144. Amsterdam/Philadelphia: John Benjamins.

St. Andre, J. 2009. Relay. In Routledge encyclopedia of translation studies (2nd ed.), eds. M. Baker and G. Saldanha, 230-232. London: Routledge. 